\title{
1 Impaired Scaling of Step Length in Parkinsonian Postural Instability
}

2 Robert A. McGovern, MD¹, Juan C. Cortés, $\mathrm{MD}^{2}$, Anne P. Wilson, MD³, Guy M. McKhann II,

$3 \quad \mathrm{MD}^{3}$, Pietro Mazzoni, $\mathrm{MD} \mathrm{PhD}{ }^{4}$

5 Affiliations:

6 1. Department of Neurosurgery, University of Minnesota, Minneapolis, MN

7 2. Department of Neurology, Johns Hopkins University, Baltimore, MD

8 3. Departments of Neurology and Neurosurgery, Columbia University, New York, NY

9 4. Department of Neurology, Washington University in St. Louis, St. Louis, MO

11 Corresponding author:

12 Pietro Mazzoni

13 Washington University in St. Louis

14660 S. Euclid Ave., CB 8111

15 St. Louis, MO 63110

16 Phone: $314-747-7036$

17 Email: mazzonip@wustl.edu

Word Count: [Abstract: 250; Body: 3670]

Running Title: Hypokinesia in parkinsonian postural instability

Keywords: Pull test; Parkinson's disease; Motor control; Bradykinesia; Falls

Financial Disclosure/Conflict of Interest: The authors do not have any financial information to disclose related to the work described in this article.

Funding Sources: This study was supported by grants from the Parkinson's Disease Foundation and the Doris Duke Charitable Foundation. 
medRxiv preprint doi: https://doi.org/10.1101/2020.08.25.20179945; this version posted August 31, 2020. The copyright holder for this preprint (which was not certified by peer review) is the author/funder, who has granted medRxiv a license to display the preprint in perpetuity.

All rights reserved. No reuse allowed without permission.

\section{Abstract}

32 Background: Postural stepping is an important strategy for recovery of balance in response to

33 postural perturbations. It is disrupted by Parkinson's disease (PD) and other conditions. The

34 nature of this disruption remains poorly understood. Understanding the motor control nature of

35 this impairment can guide the development of novel interventions.

36 Objectives: To identify the motor control abnormalities responsible for parkinsonian impairment

37 of postural stepping.

38 Methods: We studied four groups of participants: control, aged, PD, and normal-pressure

39 hydrocephalus (NPH). We performed kinematic analysis of postural stepping by recording

40 participants' body motion during a modified version of the clinical pull test, which was

41 performed multiple times with different amounts of pulling forcefulness.

42 Results: Successful postural stepping in the control group was accompanied by linear scaling of

43 their first step's length and latency to the body's initial motion: more forceful pulls caused larger

44 initial body acceleration, which resulted in longer steps that began earlier. PD patients exhibited

45 reduced scaling of step length: they maintained normal reaction time but took steps that were

46 inadequately short. Reduced step length scaling was present, but less severe, in aged individuals,

47 and was more severe in NPH patients. Aged individuals and PD patients exhibited partial

48 compensation for reduced step length scaling: their step length included a component that was

49 independent of initial body acceleration, which was absent in control and NPH groups.

50 Conclusions: the impairment of postural stepping caused by PD and related conditions is due to

51 inadequate scaling of movement amplitude and is thus a form of hypokinesia. 
medRxiv preprint doi: https://doi.org/10.1101/2020.08.25.20179945; this version posted August 31, 2020. The copyright holder for this preprint (which was not certified by peer review) is the author/funder, who has granted medRxiv a license to display the preprint in perpetuity.

All rights reserved. No reuse allowed without permission.

\section{Introduction}

53 When standing in a bus that starts moving, we must sometimes take a step back to avoid falling.

54 This behavior is an example of the postural stepping response, an important motor strategy that

55 helps us maintain balance in response to postural perturbations.

56 We can counter small perturbations by adjusting our body's geometry without moving our feet

57 (hip and ankle strategies) [1]. These strategies are inadequate, however, for a variety of

58 perturbations encountered in daily life, such as stumbling on a curb, being nudged when standing

59 in a crowd, and stepping off an escalator. Postural stepping is a commonly used strategy when

60 there are no constraints on foot movement [2]. It can counter a wide variety of perturbation types

61 and magnitudes [3,4], as it allows balance recovery by changing the body's base of support.

62 Balance disorders are an important cause of falls, which in turn are a major cause of morbidity,

63 mortality, and reduced quality of life in the elderly and in patients with neurologic disorders [5-

64 7]. The balance disorder caused by Parkinson's disease (PD) and related conditions

65 (parkinsonism) is characterized by impaired postural stepping, as exhibited in inadequate

66 responses to the pull test [8]. The nature of this impairment, however, remains unclear.

67 Studies of postural stepping in PD patients [9-14] have identified reduced static sway before

68 stepping [9], particular susceptibility to backwards perturbations [15], and abnormally

69 coordinated responses (simultaneous activation of ankle, hip and trunk muscles) to surface force

70 plate translation $[9,11,12]$. PD patients also exhibit anticipatory lateral postural adjustments,

71 later-onset and shorter steps [16,17], increased weight shift time, and a base-width neutral step

72 [18]. These varied abnormalities do not readily point to a motor control problem responsible for

73 impaired postural stepping. 
medRxiv preprint doi: https://doi.org/10.1101/2020.08.25.20179945; this version posted August 31, 2020. The copyright holder for this preprint (which was not certified by peer review) is the author/funder, who has granted medRxiv a license to display the preprint in perpetuity.

All rights reserved. No reuse allowed without permission.

74 In spite of the complex sensory processing and precisely coordinated force control required to maintain balance, postural stepping can be described rather simply at the task level in kinematic

76 terms: as the body moves away from its base of support, a step is taken to extend the base of

77 support and counter the body's falling motion. The relevant perturbation is the body's movement away from a stable configuration, regardless of the nature and magnitude of the force that caused this perturbation. The relevant response is placement of the foot in the appropriate position and at the appropriate time to counter the body's motion. Successful postural stepping may thus be

81 explained by a kinematic account, i.e. by relationships between initial body motion and kinematic features of the stepping response.

83 An interesting feature of normal postural stepping is that, when pulled backwards at the waist

84 with different force magnitudes, the step length of control participants increases as force

85 increases [19]. This finding suggests that a scaling relationship exists between magnitude of

86 postural perturbation and the stepping response. We thus hypothesized that successful postural

87 stepping can be described by a kinematic control policy: when posture is perturbed, a step is

88 taken with appropriate amplitude and latency to stop the body's motion.

89 If normal postural stepping can be described kinematically, then perhaps its impairment seen in

90 PD and other conditions has a kinematic explanation: are the steps of postural stepping too short,

91 too slow, or too late, to stop the body from falling? Such a kinematic account of postural

92 stepping impairment would link parkinsonian postural instability to bradykinesia, a complex of

93 motor symptoms that includes slowness (bradykinesia itself), reduced amplitude (hypokinesia),

94 and delay in movement onset (akinesia) [20]. 
medRxiv preprint doi: https://doi.org/10.1101/2020.08.25.20179945; this version posted August 31, 2020. The copyright holder for this preprint (which was not certified by peer review) is the author/funder, who has granted medRxiv a license to display the preprint in perpetuity.

All rights reserved. No reuse allowed without permission.

95 We devised a quantitative version of a clinical maneuver commonly used to test the stepping

96 response, the pull test, in which a participant is pulled from behind and must step backwards to

97 recover balance [8]. By recording the body's motion in response to repeated pulls of varying

98 intensity, we examined relationships between postural perturbation intensity and stepping

99 kinematics. We characterized the kinematic control policy of normal postural stepping in control

100 participants, and then examined how this control is disrupted by PD and by two other conditions

101 that disrupt postural responses, normal aging and normal pressure hydrocephalus (NPH).

\section{Methods}

103 Participants

104 We studied 29 participants with no musculoskeletal disorder, dementia, or depression (Table 1):

105 control participants (Control group); older participants (Aged group); patients with PD based on

106 UK Brain Bank Criteria [21] (PD group); patients with NPH (inclusion criteria: progressive gait

107 impairment with multiple falls, cognitive symptoms, urinary incontinence, and communicating

108 hydrocephalus disproportionate to cerebral atrophy). PD patients were tested on their usual

109 medications. The study protocol was approved by the Institutional Review Board.

110 Quantitative Pull Test Protocol

111 Participants were pulled from behind by one of us (P.M.) with a firm brisk pull at the shoulders

112 [22] and were caught if they did not recover balance on their own. This procedure was repeated

113 for 8-20 trials with varying degrees of pull intensity. A Proreflex camera (Qualisys AB) captured

114 motion of the right shoulder, elbow, hip, knee, toe, and heel in the sagittal plane. Participants

115 held their arms folded to prevent reflective marker occlusion. 
medRxiv preprint doi: https://doi.org/10.1101/2020.08.25.20179945; this version posted August 31, 2020. The copyright holder for this preprint (which was not certified by peer review) is the author/funder, who has granted medRxiv a license to display the preprint in perpetuity.

All rights reserved. No reuse allowed without permission.

Data Analysis

117 We recorded the number of steps (steps taken before stopping) and failure rate (fraction of trials

118 without recovery after 3 steps). We calculated the body's center of mass (COM) position using

119 standard biomechanical equations [23]. We differentiated COM and foot position to obtain COM

120 and foot velocity and acceleration.

121 A pull test trial consisted of an initial backward motion of the upper body (perturbation phase;

122 Fig. 1A), followed by one or more backward steps (response phase; Fig 1B). Pull onset was the

123 time when COM acceleration exceeded $15 \mathrm{~cm} / \mathrm{s}^{2}$. Step onset and landing were the times when

124 the ankle marker's velocity crossed a $3 \mathrm{~cm} / \mathrm{s}$ threshold for the first step (Fig. 1C). We quantified

125 perturbation intensity as the average COM acceleration after pull onset and before step onset

126 (shaded area in lower panel of Fig. C). The response (first step) was characterized by reaction

127 time (time to step onset; Fig. 1C), horizontal amplitude (step length), and duration (time from

128 step onset to step landing).

\section{Statistical Analysis}

130 We computed linear correlation between selected kinematic variables. We performed ANOVA

131 with corrections for multiple comparisons using Tukey's method of Honest Significant

132 Differences (JMP, SAS Institute), and with significance set at alpha $=0.05$.

\section{Results}

134 Participants did not differ in sex ratio, height, weight, or cognitive scores (Montreal Cognitive 135 Assessment [24]). Control participants were younger than other groups, as intended (Table 1).

136 PD and NPH participants had similar UPDRS III scores. Pull test scores differed across groups

137 (ANOVA, $\mathrm{p}<0.0001$ ): Control and Aged participants exhibited normal recovery (pull test score 
medRxiv preprint doi: https://doi.org/10.1101/2020.08.25.20179945; this version posted August 31, 2020. The copyright holder for this preprint (which was not certified by peer review) is the author/funder, who has granted medRxiv a license to display the preprint in perpetuity.

All rights reserved. No reuse allowed without permission.

138 0); PD and NPH had higher pull test scores than Control and Aged groups ( $t$ test, $\mathrm{p}<0.05)$; and

139 NPH had higher pull test scores than PD participants ( $t$ test, $\mathrm{p}=0.002$; Table 1$)$.

140 Participants differed in number of steps (steps taken before stopping) and failure rate (fraction of

141 trials without recovery after 3 steps; Table 1; ANOVA, $<<0.001$ ). Control participants all

142 recovered in one step in all trials, regardless of pull intensity. Aged and PD groups more steps

143 than Control $(\mathrm{p}<0.05)$ and less than NPH $(\mathrm{p}<0.01)$. NPH participants failed more frequently than

144 Control and Aged $\mathrm{p}<0.01)$.

145 Because all control participants recovered their balance in once step, we focused our analysis on

146 the first step. We looked for group differences in first step features that might explain why

147 participants in PD and NPH groups had higher failure rates.

148 The kinematics of a successful trial illustrate how postural stability may be regained after a pull.

149 The COM initially accelerated backward after a pull, away from its initial position under the base

150 of support (arrows in Fig. 1A; upper panel of Fig. 1D). The first step landed well behind the

151 COM, which stopped the COM's backward motion and restored postural stability (Fig. 1B; upper

152 panel of Fig. 1D). Failure to recover is illustrated in a trial for an NPH participant (Fig. 1D,

153 lower panel). After a short first step, the COM continued to move backwards in spite of

154 additional short steps.

155 Initial COM acceleration values varied widely, as intended, within each participant, and ranged

156 between 20 and $340 \mathrm{~cm} / \mathrm{s}^{2}$. We examined the time course of COM velocity after the first step to

157 establish how quickly participants regained their balance in a subset of trials with matched initial

158 COM acceleration. Control participants' speed decreased from the end of the first step ( $\mathrm{t}=0)$ to

159 near 0 at $\mathrm{t}=1 \mathrm{~s}$ (Fig. 2A). Aged participants' speed decreased to the same value as Control at $\mathrm{t}=1 \mathrm{~s}$ 
medRxiv preprint doi: https://doi.org/10.1101/2020.08.25.20179945; this version posted August 31, 2020. The copyright holder for this preprint (which was not certified by peer review) is the author/funder, who has granted medRxiv a license to display the preprint in perpetuity.

All rights reserved. No reuse allowed without permission.

160 (Tukey HSD; $p>0.1)$, though their intermediate speeds were higher than for Control $(p=0.0003$ at

$1610.25 \mathrm{~s} ; \mathrm{p}<0.0001$ at $0.5 \mathrm{~s})$. PD participants' speed was higher than for Control $(\mathrm{p}=0.0002)$ and

162 Aged $(\mathrm{p}<0.05)$ groups at $\mathrm{t}=1 \mathrm{~s}$. NPH participants' speed remained the highest across groups at

$163 \mathrm{t}=1 \mathrm{~s}(\mathrm{p}<0.0001$ vs PD group speed). Thus, PD and NPH participants were still moving 1 second

164 after the first step ended. These results are consistent with the groups' rankings in number of

165 steps and failure rates (Table 1).

166 Pulls of greater intensity caused faster and larger changes in COM position (Fig. 2B, upper

167 panel), which were followed by steps of earlier onset, shorter duration, and larger amplitude (Fig.

168 2B, lower panel). This finding suggests a kinematic control policy for postural stepping: step

169 latency and amplitude are scaled to the intensity of postural perturbation, so that the foot lands

170 sufficiently behind the COM to stop its motion. We examined Control participants' responses for

171 evidence of this policy and then examined how it might be disrupted in the other groups.

172 There was a marked linear correlation between step length and initial COM acceleration, both

173 within and across Control participants (Figure 3A, 3B; $r=0.80 \pm 0.2$, mean $\pm \mathrm{SEM}$; $\mathrm{p}<0.01$ for

174 each participant). Similarly, there was an inverse correlation between reaction time and initial

175 COM acceleration, (Figure 4A, 4B; $r=0.68 \pm 0.2 ; \mathrm{p}<0.05$ in each participant). By contrast, first

176 step duration did not significantly vary across trials (ANOVA, $\mathrm{p}>0.05$, mean $r=0.35 \pm 0.2$ ).

177 These correlations are a plausible mechanism for stepping responses' success: larger

178 perturbations are handled by making the first step of larger amplitude and earlier onset, so that

179 the foot lands further behind the moving body and has a better chance of halting its motion.

180 The correlation of step length and initial COM acceleration is characterized by a slope and a y-

181 intercept. The slope indicates how much longer the step is in response a larger initial acceleration 
medRxiv preprint doi: https://doi.org/10.1101/2020.08.25.20179945; this version posted August 31, 2020. The copyright holder for this preprint (which was not certified by peer review) is the author/funder, who has granted medRxiv a license to display the preprint in perpetuity.

All rights reserved. No reuse allowed without permission.

182

183

184

185

186

187

188

and represents a scaling factor between acceleration and step length. The correlation between step length and initial COM acceleration had a lower slope in the Aged, PD, and NPH groups compared to Control (Figure 3B, 3C; ANOVA, p<0.0001, Control vs. Aged, Tukey HSD, $p=0.002$, Control vs. PD, Tukey HSD, $p=0.0003$, Control vs. NPH, Tukey HSD, $p<0.0001$ ). Aged participants had a higher slope than NPH participants (Aged vs. NPH, Tukey HSD, $\mathrm{p}=0.04$ ), but otherwise slope was not significantly different among Aged, PD, and NPH groups ( $\mathrm{p}>0.05$ for all other comparisons, Tukey HSD).

The correlation's y-intercept indicates, in practice, the smallest possible step that a participant takes in response to the smallest possible initial COM acceleration. It raises the entire correlation line by this amount, and thus indicates a bias--a minimum amount of step length that is added to every step, regardless of perturbation magnitude. The step length correlation's intercept was higher in Aged and PD groups compared to Control (Figure 3B, 3D; Aged vs. Control, Tukey HSD, $p=0.006$, PD vs. Control, Tukey HSD, $p=0.02$ ), and smaller in the NPH group compared to Aged (Tukey HSD, $\mathrm{p}=0.04)$.

The lower slope values indicate that the step length of Aged, PD, and NPH participants did not increase by a normal amount in response to increasing perturbations. For sufficiently large COM accelerations, step length of Aged and PD participants was smaller than for Control (Figure 4B). Step length in the NPH group was shorter than for the Control group for most of the range of COM accelerations (Figure 4B). The higher intercept values of Aged and PD participants, on the other hand, made their steps longer than they would have otherwise been. As a result, for Aged and PD groups, the first step was longer than necessary in the range of smaller COM accelerations, and less abnormally short for larger COM accelerations (Figure 4B). An increase 
medRxiv preprint doi: https://doi.org/10.1101/2020.08.25.20179945; this version posted August 31, 2020. The copyright holder for this preprint (which was not certified by peer review) is the author/funder, who has granted medRxiv a license to display the preprint in perpetuity.

All rights reserved. No reuse allowed without permission.

204 in the intercept thus countered the effect of slope reduction and partially compensated for the

205 loss of adequate scaling of step size to perturbation magnitude in Aged and PD groups. For

206 example, step length for the PD group was shorter than normal only for accelerations above $\sim 100$

$207 \mathrm{~cm} / \mathrm{s}^{2}$ (Figure 4B) because of the higher intercept of this group's correlation. This effect was not

208 seen in the NPH group.

209 The correlation between reaction time and initial COM acceleration did not significantly vary

210 across groups (Figure 4; slope, ANOVA, $\mathrm{p}=0.45$, all Tukey HSD comparisons, $\mathrm{p}>0.45$; intercept,

211 ANOVA, $\mathrm{p}=0.10$, all Tukey HSD comparisons, $\mathrm{p}>0.08$ ).

\section{Discussion}

213 Kinematic analysis of a clinical test of postural stability revealed that the normal response to

214 postural perturbations across a wide range of intensities is to recover by scaling the first step's

215 amplitude and latency to the body's initial acceleration. These scaling relationships indicate a

216 kinematic strategy for successful recovery from postural perturbations of different intensities:

217 increasing step length and decreasing reaction time allows the body to recover balance by

218 placing the foot further behind the center of mass, and sooner, in response to greater postural

219 perturbations.

220 Aged participants successfully recovered but took more than one step. PD and NPH participants

221 took more steps and had higher failure rates. The slope of the correlation between step length and

222 postural perturbation magnitude was reduced in all 3 groups, and its intercept was increased in

223 Aged and PD groups. Reaction time scaling to postural perturbation was normal in Aged, PD,

224 and NPH groups. 
medRxiv preprint doi: https://doi.org/10.1101/2020.08.25.20179945; this version posted August 31, 2020. The copyright holder for this preprint (which was not certified by peer review) is the author/funder, who has granted medRxiv a license to display the preprint in perpetuity.

All rights reserved. No reuse allowed without permission.

225 The slope reduction in step length scaling in Aged, PD, and NPH groups offers a kinematic

226 explanation for failure to recover balance in the pull test. For larger perturbations, step size was

227 abnormally small, so that the foot was not placed far enough behind the body to stop its motion.

228 Aged participants exhibited the same type of postural stepping abnormality, reduced step length

229 scaling, as PD participants, though this reduction was less than in the PD group. Aged and PD

230 groups also exhibited a compensatory increase in the intercept of the correlation between body

231 acceleration and step size. This compensatory change was of similar magnitude in both groups. It

232 may have been sufficient to counter the smaller amount of slope reduction in the Aged group and

233 thus explain their lower failure rate in the pull test (Table 1). The intercept increase may have not

234 been sufficient to counter the larger slope reduction of the PD group, which potentially accounts

235 for the group's higher failure rate.

236 Regarding the symptom complex of bradykinesia (bradykinesia proper, hypokinesia, akinesia;

237 see Introduction) [20], our findings indicate a postural stepping abnormality that consists of

238 hypokinesia: steps were shorter than they needed to be to allow balance recovery in PD and NPH

239 groups. By contrast, these participants did not show evidence of delayed movement onset

240 (akinesia). This finding could reflect normal control of step reaction time in the groups we

241 studied, or a combined effect of reaction time increase, known to be caused by PD [25] and

242 compensatory reaction time reduction to counteract first step hypokinesia. Similarly, there was

243 no evidence of movement slowing.

244 Finding a similar motor control abnormality underlying abnormal postural stepping across Aged,

245 PD, and NPH groups suggests that these conditions share brain changes responsible for postural

246 instability. A shared pathology for PD and NPH is consistent with the overlap of other clinical 
medRxiv preprint doi: https://doi.org/10.1101/2020.08.25.20179945; this version posted August 31, 2020. The copyright holder for this preprint (which was not certified by peer review) is the author/funder, who has granted medRxiv a license to display the preprint in perpetuity.

All rights reserved. No reuse allowed without permission.

manifestations of these disorders, such as bradykinesia of rapid repeated leg and foot movements

248 [26]. Similarly, aging is accompanied by brain changes also seen in PD, including loss of

249 neurons in the substantia nigra and parkinsonian movement abnormalities [27]. In aging,

250 however, these abnormalities may be subclinical, rather than entirely absent, thanks to

251 compensatory mechanisms like the rise in the intercept of the step length scaling relationship.

252 The lack of evidence of compensation (increase in intercept) in the NPH group may indicate that

253 compensatory mechanisms are not available when kinematic scaling relationships are severely

254 disrupted: NPH participants' slopes for the step size vs. initial acceleration scaling were nearly

255 flat. Alternatively, NPH may disrupt additional gait control mechanisms not affected by aging or

256 PD.

257 Elderly individuals are known to take multiple steps when recovering from a postural

258 perturbation [28-31]. Step kinematics differed from those of young participants in some studies

$259[29,31]$ but were normal in another study [30]. Our results may explain this variation as

260 emerging from the changes in the scaling relationship of step length to perturbation magnitude.

261 Thanks to the compensatory effect of increased intercept, aged participants in our study took

262 abnormally short steps only for perturbations greater than $150 \mathrm{~cm} / \mathrm{s}^{2}$ (Fig. 3B).

263 PD patients have been reported to take abnormally short steps in compensatory stepping, as we

264 found, but also to exhibit increased reaction time, unlike our findings [17]. Differences in how

265 perturbations were applied may account for this discrepancy: platform motion is likely more

266 sudden than a manual pull at the shoulders, and could thus unmask reaction time increases not

267 visible in the pull test. Another study [18] did not find an effect of PD on step length, which we

268 also found for initial body accelerations below $100 \mathrm{~cm} / \mathrm{s}^{2}$. Some of these findings, such as 
medRxiv preprint doi: https://doi.org/10.1101/2020.08.25.20179945; this version posted August 31, 2020. The copyright holder for this preprint (which was not certified by peer review) is the author/funder, who has granted medRxiv a license to display the preprint in perpetuity.

All rights reserved. No reuse allowed without permission.

reduced static sway, may reflect the same kinematic abnormality (hypokinesia) we identified, while others may be independent additional contributors to impaired postural stepping.

Postural response impairment in PD has been examined within a model of standing as the balancing of a two-segment inverted pendulum, in which the CNS acting as a multivariate feedback controller that processes sensory information, estimates body kinematics, and sends appropriate motor commands scaled by feedback gains [32]. PD patients in this study had abnormal feedback gains and were unable to scale postural responses to changes in perturbation amplitude. Although these results were observed in a fixed-support postural task, the model offers a convincing mechanism to explain our findings for normal and abnormal stepping responses. Consistent with this model, our findings show that the normal stepping response is governed by a linear gain between perturbation magnitude and postural response, and that PD reduces this gain so that postural responses are scaled down.

While gait parameters have been studied in detail for NPH patients [33], our understanding of postural control in these patients remains limited. NPH patients appear to have a larger static sway area and higher backwards directed COM velocity during upright stance [34], but no dynamic studies have examined NPH patients' postural control in detail. The patients in our study were essentially unable to scale step length to increases in perturbation amplitude. This resulted in the highest percentage of inadequate responses among the groups we studied.

We chose the COM's initial backward acceleration as the measure of perturbation intensity, rather than the force applied at the shoulders. The COM's initial acceleration results from the combined effect of pull force and inertial resistance due to a person's mass, height, posture, and stiffness (mechanical impedance). COM acceleration thus reflects the effective intensity of the 
medRxiv preprint doi: https://doi.org/10.1101/2020.08.25.20179945; this version posted August 31, 2020. The copyright holder for this preprint (which was not certified by peer review) is the author/funder, who has granted medRxiv a license to display the preprint in perpetuity.

All rights reserved. No reuse allowed without permission.

291 pull, that is, how effectively a pull's force displaces the body away from a stable posture. We

292 would argue that the relevant variable that ultimately leads to loss of balance is the body's

293 motion towards the limits of the base of support, and not the force applied at the shoulders. The

294 body's motion is what needs to be countered: a fall is, after all, the end-result of the COM being

295 in the wrong position, and headed in the wrong direction, relative to the base of support for too

296 long. Therefore, even though COM acceleration is not an independent variable (as it is an

297 outcome of the applied force), we consider it an appropriate measure of perturbation intensity in

298 the pull test.

299 An advantage of using COM acceleration as a measure of perturbation intensity is that it is not

300 confounded by anticipatory strategies. If participants leaned forward or stiffened their body in

301 anticipation of the pull, the effect of a given pull force would be diminished. These strategies are

302 equivalent to increasing inertial resistance. Their dampening effect on applied force is thus

303 accurately reflected in the COM's initial acceleration and does not confound the estimate of

304 perturbation intensity.

305 A kinematic explanation of postural instability as a manifestation of hypokinesia suggests that

306 postural responses should improve with treatments that benefit other forms of hypokinesia. At

307 this time, whether any treatment improves postural instability is in our opinion unclear.

308 Treatment of PD with levodopa is associated with reduced frequency of falls [35] and with

309 improved scores on all motor subcomponents of the UPDRS, including the subscale related to

310 postural control and gait [36]. However, levodopa worsened the ability to scale responses to

311 large perturbation amplitudes in a fixed-support strategy postural task [37]. Postural instability

312 has been reported not to benefit from deep brain stimulation (DBS) when assessed with clinical 
313 measures [38], but showed clear benefit from DBS (Nantel et al., 2012) and pallidotomy [41]

314 when assessed with posturography. Compensatory stepping has been shown to be unaffected by

315 globus pallidus internus DBS while subthalamic nucleus DBS has been associated with delays in

316 the preparatory phase prior to stepping and more steps required to regain balance [42]. Treatment

317 of NPH with ventriculoperitoneal shunting has benefit on gait $[43,44]$; whether this treatment

318 improves postural responses is unclear.

319 We found that successful recovery of balance in postural stepping is mediated by a kinematic

320 mechanism (scaling of first step length and reaction time to initial body motion) and that

321 parkinsonian postural instability can be explained by hypokinesia of the first step. People with

322 parkinsonism have difficulty recovering balance because their reactive steps are too small

323 relative to the size of the imposed perturbation, and not because of a delay in step initiation.

324 Further quantitative testing of postural stepping may clarify whether treatments that are effective

325 for other forms of hypokinesia, such as dopaminergic medications and DBS, can also benefit

326 parkinsonian postural instability.

\section{Acknowledgments}

328 We thank Paul Greene and Ash Rao for discussion.

\section{Authors' Roles}

330 1) Research project: A. Conception, B. Organization, C. Execution;

331 2) Statistical Analysis: A. Design, B. Execution, C. Review and Critique;

332 3) Manuscript: A. Writing of the first draft, B. Review and Critique.

333 RAM: 1BC, 2AB, 3AB 
334 JCC: $1 \mathrm{C}, 2 \mathrm{C}, 3 \mathrm{~B}$

335 AW: $1 \mathrm{C}$

336 GMM: 1BC, 3C

337 PM: 1ABC, 2ABC, 3B

338 Financial Disclosures for Preceding 12 Months

339 Stock Ownership in medically-related fields: RAM: None; JCC: None; AW: None; GMM: None;

340 PM: None

341 Intellectual Property Rights: RAM: None; JCC: None; AW: None; GMM: None; PM: None

342 Consultancies: RAM: None JCC: None; AW: None; GMM: None; PM: None

343 Expert Testimony: RAM: None, JCC: None; AW: None; GMM: None; PM: Yes

344 Advisory Boards: RAM: Data Safety Monitoring Board, Synerfuse, Inc. JCC: None; AW: None;

345 GMM: None; PM: None

346 Partnerships: RAM: None JCC: None; AW: None; GMM: None; PM: None

347 Contracts: RAM: None JCC: None; AW: None; GMM: None; PM: None

348 Honoraria: RAM: None JCC: None; AW: None; GMM: None; PM: None

349 Royalties: RAM: None JCC: None; AW: None; GMM: None; PM: None

350 Grants: RAM: MnDRIVE; JCC: None; AW: None; GMM: None; PM: NINDS

351 Other: RAM: None JCC: None; AW: None; GMM: None; PM: None 
medRxiv preprint doi: https://doi.org/10.1101/2020.08.25.20179945; this version posted August 31, 2020. The copyright holder for this preprint (which was not certified by peer review) is the author/funder, who has granted medRxiv a license to display the preprint in perpetuity.

All rights reserved. No reuse allowed without permission.

\section{References}

3531 Horak FB, Macpherson JM. Postural Orientation and Equilibrium. In: Comprehensive

354 Physiology. American Cancer Society 2011.255-92. doi:10.1002/cphy.cp120107

3552 McIlroy W, Maki B. Task constraints on foot movement and the incidence of compensatory

356 stepping following perturbation of upright stance. Brain Res 1993;616:30-8.

3573 Maki BE, McIlroy WE. The role of limb movements in maintaining upright stance: the

358 'change-in-support' strategy. Phys Ther 1997;77:488-507.

3594 Rogers MW, Mille M-L. Chapter 5 - Balance perturbations. In: Day BL, Lord SR, eds.

360 Handbook of Clinical Neurology. Elsevier 2018. 85-105. doi:10.1016/B978-0-444-63916-

$361 \quad 5.00005-7$

3625 Sheldon J. On the natural history of falls in old age. $\operatorname{Br}$ Med J 1960;2:1685-90.

3636 Sturnieks DL, St George R, Lord SR. Balance disorders in the elderly. Neurophysiol Clin

364 Clin Neurophysiol 2008;38:467-78. doi:10.1016/j.neucli.2008.09.001

3657 Soh S-E, McGinley JL, Watts JJ, et al. Determinants of health-related quality of life in

366 people with Parkinson's disease: a path analysis. Qual Life Res Int J Qual Life Asp Treat

367 Care Rehabil 2013;22:1543-53. doi:10.1007/s11136-012-0289-1

3688 Bloem BR, Beckley DJ, van Hilten BJ, et al. Clinimetrics of postural instability in

369 Parkinson's disease. J Neurol 1998;245:669-73.

3709 Horak F, Nutt J, Nashner L. Postural inflexibility in parkinsonian subjects. J Neurol Sci

$371 \quad$ 1992;111:46-58.

37210 Adkin AL, Frank JS, Jog MS. Fear of falling and postural control in Parkinson's disease.

373 Mov Disord Off J Mov Disord Soc 2003;18:496-502. doi:10.1002/mds.10396 
medRxiv preprint doi: https://doi.org/10.1101/2020.08.25.20179945; this version posted August 31, 2020. The copyright holder for this preprint (which was not certified by peer review) is the author/funder, who has granted medRxiv a license to display the preprint in perpetuity.

All rights reserved. No reuse allowed without permission.

37411 Carpenter MG, Allum JH, Honegger F, et al. Postural abnormalities to multidirectional

375 stance perturbations in Parkinson's disease. J Neurol Neurosurg Psychiatry 2004;75:1245-

$376 \quad$ 54. doi:10.1136/jnnp.2003.021147

37712 Dimitrova D, Horak FB, Nutt JG. Postural muscle responses to multidirectional translations

378 in patients with Parkinson's disease. J Neurophysiol 2004;91:489-501.

379 doi:10.1152/jn.00094.2003

38013 Park S, Horak FB, Kuo AD. Postural feedback responses scale with biomechanical

$381 \quad$ constraints in human standing. Exp Brain Res 2004;154:417-27. doi:10.1007/s00221-003-

$382 \quad 1674-3$

38314 Ganesan M, Pal PK, Gupta A, et al. Dynamic posturography in evaluation of balance in

384 patients of Parkinson's disease with normal pull test: concept of a diagonal pull test.

385 Parkinsonism Relat Disord 2010;16:595-9. doi:10.1016/j.parkreldis.2010.08.005

38615 Horak FB, Dimitrova D, Nutt JG. Direction-specific postural instability in subjects with

387 Parkinson's disease. Exp Neurol 2005;193:504-21. doi:10.1016/j.expneurol.2004.12.008

38816 King LA, George RJS, Carlson-Kuhta P, et al. Preparation for Compensatory Forward

389 Stepping in Parkinson's Disease. Arch Phys Med Rehabil 2010;91:1332-8.

$390 \quad$ doi:10.1016/j.apmr.2010.05.013

39117 Schlenstedt C, Mancini M, Horak F, et al. Anticipatory Postural Adjustment During Self-

392 Initiated, Cued, and Compensatory Stepping in Healthy Older Adults and Patients With

393 Parkinson Disease. Arch Phys Med Rehabil 2017;98:1316-1324.e1.

394 doi:10.1016/j.apmr.2017.01.023 
medRxiv preprint doi: https://doi.org/10.1101/2020.08.25.20179945; this version posted August 31, 2020. The copyright holder for this preprint (which was not certified by peer review) is the author/funder, who has granted medRxiv a license to display the preprint in perpetuity.

All rights reserved. No reuse allowed without permission.

39518 McVey MA, Amundsen S, Barnds A, et al. The effect of moderate Parkinson's disease on

396 compensatory backwards stepping. Gait Posture 2013;38:800-5.

397 doi:10.1016/j.gaitpost.2013.03.028

39819 Luchies CW, Alexander NB, Schultz AB, et al. Stepping responses of young and old adults

399 to postural disturbances: kinematics. J Am Geriatr Soc 1994;42:506-12.

40020 Hallett M. Bradykinesia: why do Parkinson's patients have it and what trouble does it cause?

401 Mov Disord Off J Mov Disord Soc 2011;26:1579-81. doi:10.1002/mds.23730

40221 Hughes AJ, Daniel SE, Kilford L, et al. Accuracy of clinical diagnosis of idiopathic

403 Parkinson's disease: a clinico-pathological study of 100 cases. J Neurol Neurosurg

$404 \quad$ Psychiatry 1992;55:181-4.

40522 Lang A. Clinical rating scales and videotape analysis. In: Therapy of Parkinson's disease.

406 New York: : Marcel Dekker 1995. 21-46.

40723 Winter DA. Biomechanics and Motor Control of Human Movement. New York: : John Wiley

$408 \quad$ and Sons 1990.

40924 Nasreddine ZS, Phillips NA, Bedirian V, et al. The Montreal Cognitive Assessment, MoCA:

410 a brief screening tool for mild cognitive impairment. J Am Geriatr Soc 2005;53:695-9.

411 doi:10.1111/j.1532-5415.2005.53221.x

41225 Evarts EV, Teravainen H, Calne DB. Reaction time in Parkinson's disease. Brain

$413 \quad$ 1981;104:167-86.

41426 Hallett M. Parkinson Revisited: Pathophysiology of Motor Signs. In: Gordin A, Kaakkola S,

415 Teravainen H, eds. Adv Neurol. Philadelphia: : Lippincott Williams \& Wilkins 2003. 9-18.

41627 Ross GW, Petrovitch H, Abbott RD, et al. Parkinsonian signs and substantia nigra neuron

417 density in decendents elders without PD. Ann Neurol 2004;56:532-9. doi:10.1002/ana.20226 
medRxiv preprint doi: https://doi.org/10.1101/2020.08.25.20179945; this version posted August 31, 2020. The copyright holder for this preprint (which was not certified by peer review) is the author/funder, who has granted medRxiv a license to display the preprint in perpetuity.

All rights reserved. No reuse allowed without permission.

41828 Wolfson L, Whipple R, Amerman P, et al. Stressing the postural response. A quantitative

419 method for testing balance. J Am Geriatr Soc 1986;34:845.

42029 Luchies CW, Alexander NB, Schultz AB, et al. Stepping responses of young and old adults

421 to postural disturbances: kinematics. J Am Geriatr Soc 1994;42:506-12.

42230 McIlroy WE, Maki BE. Age-related changes in compensatory stepping in response to

423 unpredictable perturbations. J Gerontol A Biol Sci Med Sci 1996;51:M289.

42431 Thelen DG, Wojcik LA, Schultz AB, et al. Age differences in using a rapid step to regain

$425 \quad$ balance during a forward fall. J Gerontol A Biol Sci Med Sci 1997;52:M8.

42632 Kim S, Horak FB, Carlson-Kuhta P, et al. Postural feedback scaling deficits in Parkinson's

33 Stolze H, Kuhtz-Buschbeck JP, Drucke H, et al. Comparative analysis of the gait disorder of normal pressure hydrocephalus and Parkinson's disease. J Neurol Neurosurg Psychiatry

43134 Blomsterwall E, Svantesson U, Carlsson U, et al. Postural disturbance in patients with normal pressure hydrocephalus. Acta Neurol Scand 2000;102:284-91.

43335 Parashos SA, Bloem BR, Browner NM, et al. What predicts falls in Parkinson disease?:

434 Observations from the Parkinson's Foundation registry. Neurol Clin Pract 2018;8:214-22.

435 doi:10.1212/CPJ.0000000000000461

$43636 \mathrm{Vu}$ TC, Nutt JG, Holford NHG. Progression of motor and nonmotor features of Parkinson's 437 disease and their response to treatment. Br J Clin Pharmacol 2012;74:267-83.

438 doi:10.1111/j.1365-2125.2012.04192.x

43937 Horak FB, Frank J, Nutt J. Effects of dopamine on postural control in parkinsonian subjects:

$440 \quad$ scaling, set, and tone. J Neurophysiol 1996;75:2380-96. 
medRxiv preprint doi: https://doi.org/10.1101/2020.08.25.20179945; this version posted August 31, 2020. The copyright holder for this preprint (which was not certified by peer review) is the author/funder, who has granted medRxiv a license to display the preprint in perpetuity.

All rights reserved. No reuse allowed without permission.

44138 Brandmeir NJ, Brandmeir CL, Carr D, et al. Deep Brain Stimulation for Parkinson Disease

442 Does not Worsen or Improve Postural Instability: A Prospective Cohort Trial. Neurosurgery

$443 \quad$ 2018;83:1173-82. doi:10.1093/neuros/nyx602

44439 Shivitz N, Koop MM, Fahimi J, et al. Bilateral subthalamic nucleus deep brain stimulation

445 improves certain aspects of postural control in Parkinson's disease, whereas medication does

446 not. Mov Disord Off J Mov Disord Soc 2006;21:1088-97. doi:10.1002/mds.20905

44740 Nantel J, McDonald JC, Bronte-Stewart H. Effect of medication and STN-DBS on postural

$448 \quad$ control in subjects with Parkinson's disease. Parkinsonism Relat Disord 2012;18:285-9.

449 doi:10.1016/j.parkreldis.2011.11.005

45041 Bronte-Stewart HM, Minn AY, Rodrigues K, et al. Postural instability in idiopathic

451 Parkinson's disease: the role of medication and unilateral pallidotomy. Brain J Neurol

$452 \quad 2002 ; 125: 2100-14$.

45342 St George RJ, Carlson-Kuhta P, King LA, et al. Compensatory stepping in Parkinson’s

454 disease is still a problem after deep brain stimulation randomized to STN or GPi. $J$

$455 \quad$ Neurophysiol 2015;114:1417-23. doi:10.1152/jn.01052.2014

45643 Williams M, Thomas G, Lateur B de, et al. Objective Assessment of Gait in Normal-

457 Pressure Hydrocephalus. Am J Phys Med Rehabil 2008;87:39-45.

458 doi:10.1097/PHM.0b013e31815b6461

45944 Giordan E, Palandri G, Lanzino G, et al. Outcomes and complications of different surgical

460 treatments for idiopathic normal pressure hydrocephalus: a systematic review and meta-

$461 \quad$ analysis. $J$ Neurosurg 2018;131:1024-36. doi:10.3171/2018.5.JNS1875

462 
medRxiv preprint doi: https://doi.org/10.1101/2020.08.25.20179945; this version posted August 31, 2020. The copyright holder for this preprint (which was not certified by peer review) is the author/funder, who has granted medRxiv a license to display the preprint in perpetuity.

All rights reserved. No reuse allowed without permission.

\section{Figure Legends}

464 Figure 1. Trajectories of motion capture markers from pull onset ( $\mathrm{t}=0$; grey) to $\mathrm{t}=250 \mathrm{~ms}$ (black)

465 in a pull test trial. Arrows indicate horizontal center-of-mass (COM) position. B. Marker

466 trajectories up to time of first step landing $(\mathrm{t}=670 \mathrm{~ms})$. C. Kinematic quantities in a pull test trial

467 for a CTL participant. D. Horizontal position of COM (solid), heel, toe (dashed) during a single

468 trial in individual CTL (upper traces) and NPH (lower traces) participants.

469 Figure 2. A. COM velocity after first step landing for trials with average COM acceleration

470 matched across groups. B. Time course of COM and foot (heel) position for selected trials of

471 different perturbation magnitude (randomly interleaved) in a CTL participant.

472 Figure 3. A. Step length vs. initial COM acceleration for all trials for one CTL and one PD

473 participant. Lines = linear correlation. B. Correlation lines between step length and initial COM

474 acceleration. Shading $=$ standard error. C. Slope $($ mean \pm SEM $)$ of linear correlation between

475 step length and initial COM acceleration. *, $\mathrm{p}<0.05 ; * *, \mathrm{p}<0.01 ; * * *, \mathrm{p}<0.001$ (Tukey HSD

476 contrasts). D. Intercept (mean \pm SEM) of linear regression between step length and initial COM

477 acceleration.

478 Figure 4. A. Reaction time vs. initial COM acceleration for all trials for one CTL and one PD

479 participant. Lines $=$ linear correlation. B. Correlation lines between reaction time and initial

480 COM acceleration for each participant group. C. Slope (mean $\pm \mathrm{SEM}$ ) of linear regression

481 between reaction time and initial COM acceleration. ${ }^{*}, \mathrm{p}<0.05 ; * *, \mathrm{p}<0.01 ; * * *, \mathrm{p}<0.001$ (Tukey

482 HSD contrasts). D. Intercept (mean \pm SEM) of linear regression between reaction time and initial

483 COM acceleration. 

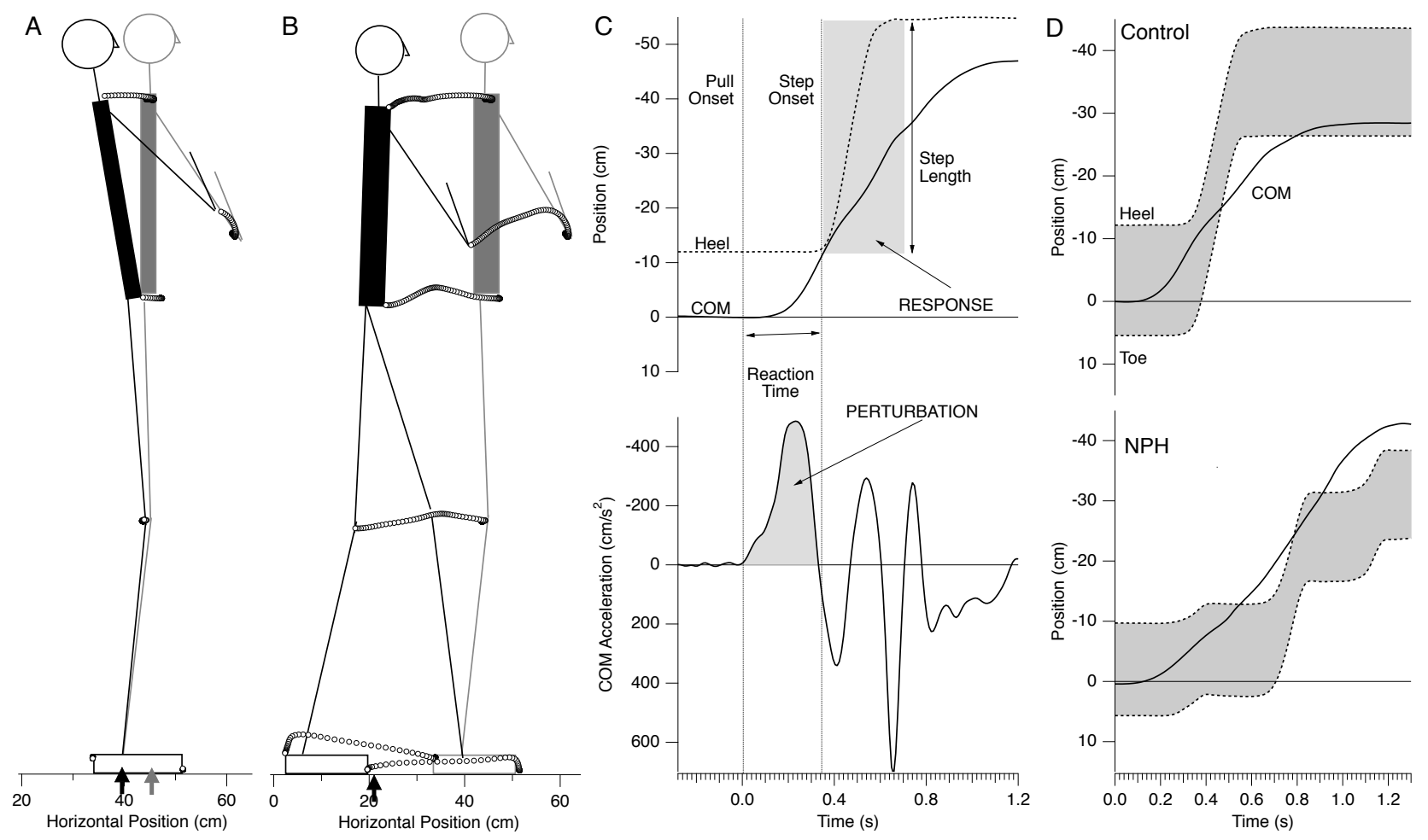

Figure 1 

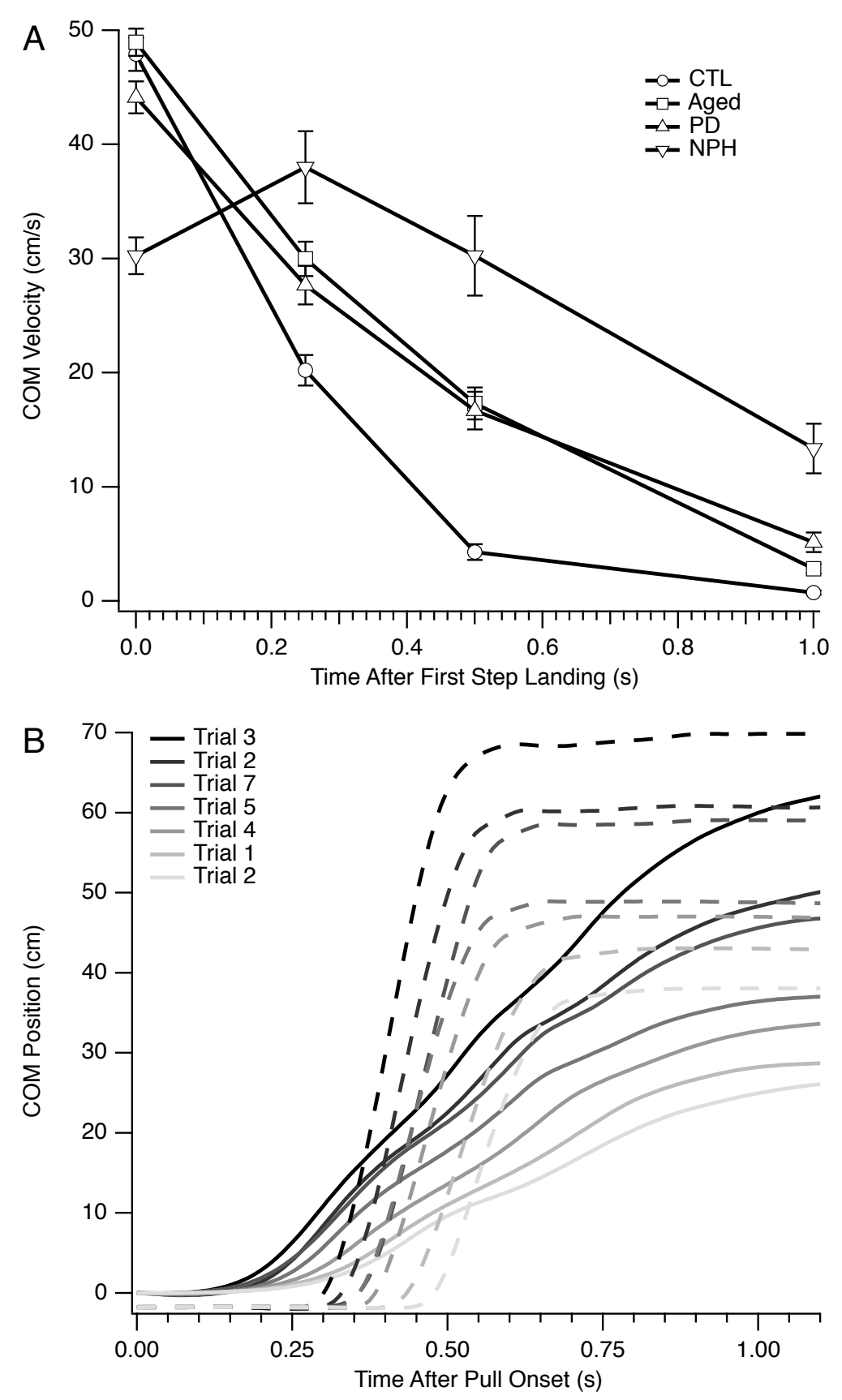

Figure 2 

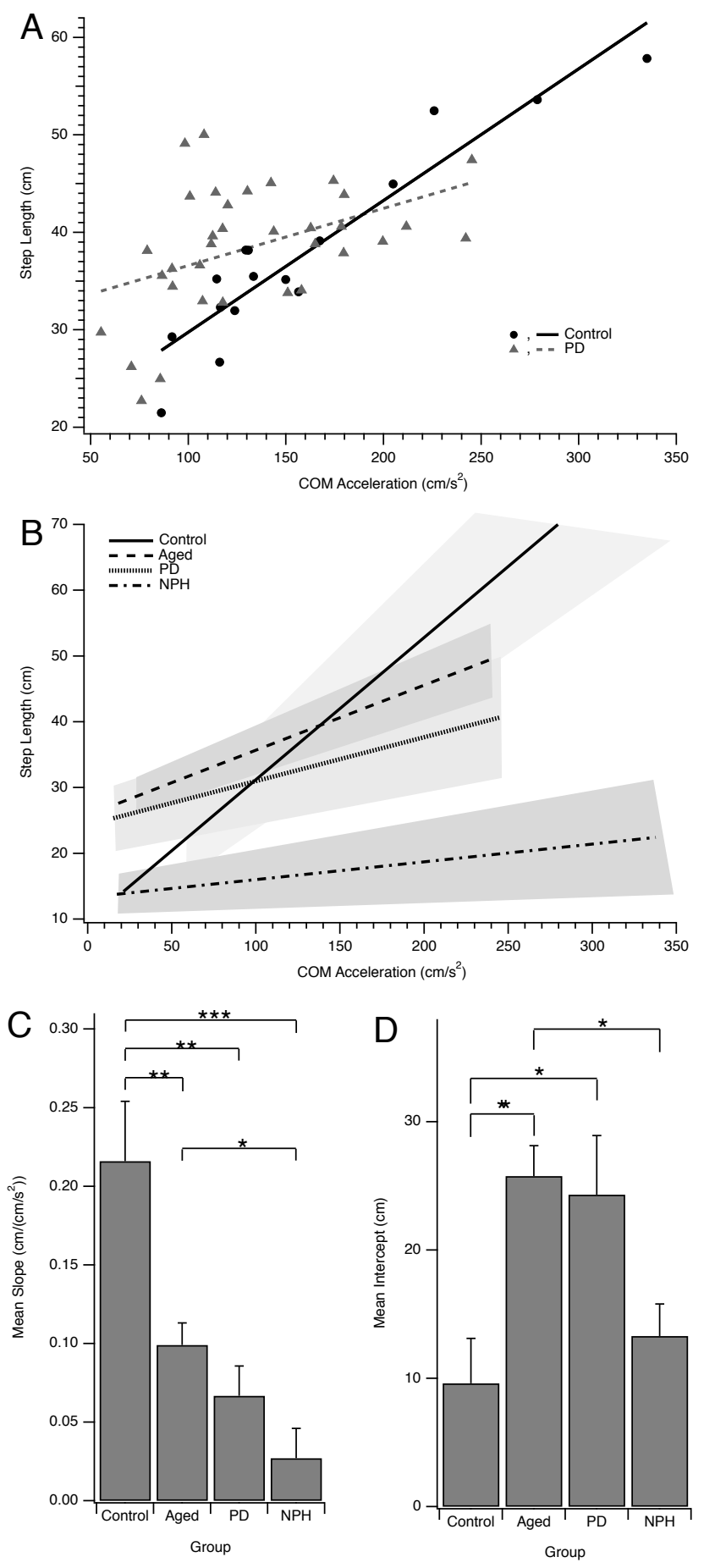

Figure 3 

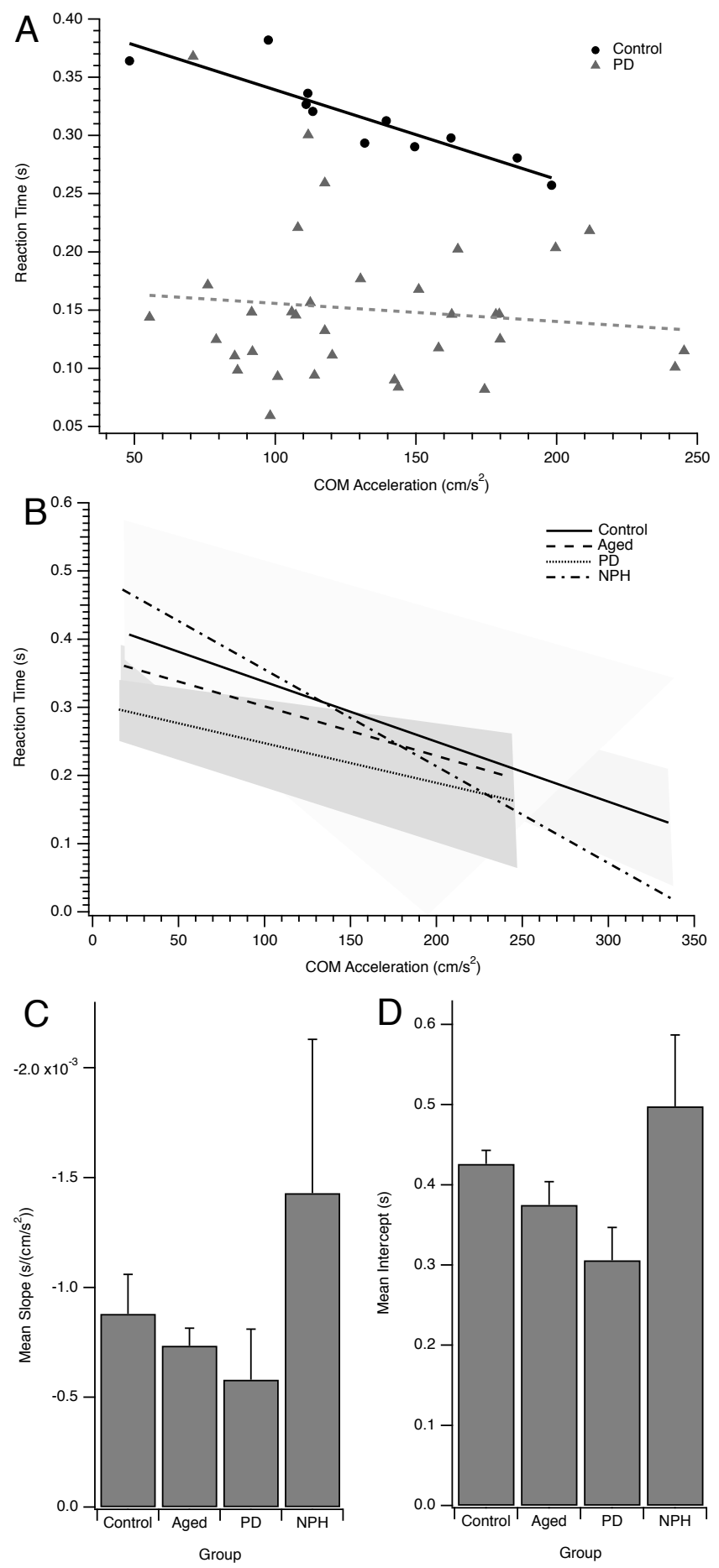

Figure 4 